\title{
Correlation between Critical Pitting Temperature and Degree of Sensitization of UNS S32750 Duplex Stainless Steel Corrosion
}

M. Sun ${ }^{l}, L . H e^{1, *}, X . Q . L i^{l}, P . L i^{1}$

School of Materials Engineering, Shanghai University of Engineering Science, Shanghai 201620,

China

*E-mail: j1ljhl@163.com

doi: $10.20964 / 2020.02 .42$

Received: 7 October 2019 / Accepted: 19 November 2019 / Published: 31 December 2019

This study aims to explore the correlation of critical pitting temperature (CPT) and degree of sensitization (DOS) for UNS S32750 duplex stainless steel after being exposed to different heat conditions. Both the CPT and DOS are strongly dependent on the microstructure. It is also revealed that the pitting resistance heals after prolonging the ageing time, but the degree of sensitization continues to increase.

Keywords: Duplex Stainless Steel, Pitting Corrosion, Intergranular Corrosion, CPT, DOS

\section{$\underline{\text { FULL TEXT }}$}

(C) 2020 The Authors. Published by ESG (www.electrochemsci.org). This article is an open access article distributed under the terms and conditions of the Creative Commons Attribution license (http://creativecommons.org/licenses/by/4.0/). 